\title{
Chemical Changes and Optimisation of Acetous Fermentation Time and Mother of Vinegar Concentration in the Production of Vinegar-like Fermented Papaya Beverage
}

(Perubahan Kimia dan Pengoptimuman Masa dan Kepekatan Ibu Cuka untuk Fermentasi Asetus dalam Penghasilan Minuman Buah Betik Terfermentasi Serupa-Cuka)

\author{
Ching Ting Kong, Chin Wai Ho, Jin Wei Alvin Ling, AzWan LaZim, Shazrul Fazry \& SEng Joe LiM*
}

\begin{abstract}
Fermentation has been long used as a method to produce beverage of various health benefits. In this research, ripe papaya (Carica papaya) was fermented through alcoholic fermentation using Saccharomyces cerevisiae, followed by acetous fermentation using Acetobacter spp. from mother of vinegar, to reduce wastage of this highly perishable Malaysian fruit. The papaya juice was pasteurised prior to the fermentation process. Optimisation of acetous fermentation was carried out using the response surface methodology (RSM) with central composite rotatable design (CCRD). Acetous fermentation time had shown significant effect on all the chemical characteristics while mother of vinegar concentration did not significantly effect on all the chemical characteristics. The vinegar-like fermented papaya beverage which was produced at the optimum point (Fermentation time $=70.80 \mathrm{~h}$ and concentration $=40 \%$ mother of vinegar) contained $0.37 \pm 0.01 \%$ reducing sugar, $3.54 \pm 0.36 \%$ ethanol, $2.46 \pm 0.07 \%$ acetic acid, $327.89 \pm 3.60 \mathrm{mg}$ GAE/ L total phenolic, $2.32 \pm 0.17 \mathrm{mg} / 100 \mathrm{~mL}$ ascorbic acid and $52.40 \pm 0.23 \% \mathrm{mg} \mathrm{AA} / 100 \mathrm{~mL}$ free-radical scavenging activity. In conclusion, vinegar-like fermented papaya beverage was successfully produced and its chemical compositions changed from papaya juice to wine and vinegar-like beverage with increased bioactive compounds and antioxidative activity.
\end{abstract}

Keywords: Acetous; alcohol; fermentation; optimisation; papaya

ABSTRAK

Fermentasi merupakan kaedah yang telah lama digunakan untuk menghasilkan minuman dengan pelbagai faedah kesihatan. Dalam kajian ini, buah betik (Carica papaya) yang ranum telah difermentasi melalui fermentasi alkohol oleh Saccharomyces cerevisiae dan fermentasi asetus oleh Acetobacter spp. daripada ibu cuka bagi mengurangkan pembaziran buah Malaysia yang mudah rosak ini. Jus betik telah dipasteurkan sebelum diperlakukan dengan proses fermentasi. Pengoptimuman fermentasi asetus telah dijalankan melalui kaedah respons permukaan (RSM) dengan reka bentuk berputar komposit berpusat (CCRD). Masa fermentasi asetus mempunyai kesan yang bererti kepada semua ciri kimia manakala kepekatan ibu cuka tidak memberi kesan yang signifikan ke atas semua ciri kimia tersebut. Minuman terfermentasi buah betik serupa-cuka yang dihasilkan pada titik optimum fermentasi asetus (Masa fermentasi $=70.80$ jam dan kepekatan $=40 \%$ ibu cuka) mengandungi $0.37 \pm 0.01 \%$ gula, $3.54 \pm 0.36 \%$ etanol, $2.46 \pm 0.07 \%$ asid asetik, $327.89 \pm 3.60 \mathrm{mg} \mathrm{GAE} / \mathrm{L}$ jumlah fenolik, $2.32 \pm 0.17 \mathrm{mg} / 100 \mathrm{~mL}$ asid askorbik dan $52.40 \pm 0.23 \% \mathrm{mg}$ AA/100 mL aktiviti pemerangkapan radikal bebas DPPH. Secara kesimpulannya, minuman terfermentasi buah betik serupa-cuka telah berjaya dihasilkan dan perubahan komposisi kimia daripada jus kepada wain dan minuman betik serupa-cuka menunjukkan peningkatan sebatian bioaktif dan aktiviti antioksida.

Kata kunci: Alkohol; asetus; buah betik; cuka; fermentasi; pengoptimuman

\section{INTRODUCTION}

According to the Malaysian Food Regulations (1985) (Regulation 334), vinegar is a solution which contains not less than $4 \mathrm{~g}$ acetic acid in $100 \mathrm{~mL}$ that is produced from alcoholic fermentation and subsequently acetous fermentation. The earliest methods used for producing vinegar include Orléans method, generator method and submerged-culture method (Ho et al. 2017a; Morales et al. 2001). Generator method and submerged-culture method have been developed and used for recent commercial vinegar production. Vinegar processing eventually includes filtration, distillation and pasteurisation before it is packaged in bottle (Fatima \& Mishra 2015).

Traditionally, vinegar is used as food preservative because it stops microbial growth (Lingham et al. 2012). Besides, vinegar contributes to sensory characteristics of food such as sauce, mayonnaise and salad dressing (Ho et al.2017a). However, most manufacturers prefer to produce synthetic vinegar due to its shorter fermentation time and lower cost. In traditional vinegar production, it requires 
fermentation time of 6-8 weeks, which is undesirable as it increases cost of production (Fatima \& Mishra 2015). In Malaysia, ordinary pure vinegar production is only produced in rural industry using variety of agricultural products and by-products as substrate such as coconut sap, nipah sap and fruit juices (Fatima \& Mishra 2015). Vinegar were also produced using tropical fruits, such as soursop (Ho et al. 2017b), pineapple (Akubor 2017; Mohamad et al. 2015), mango and banana (Coelho et al. 2017).

Papaya is believed to be originated from Central America. For the Maya civilization, papaya is one of their important fruits hence the papaya tree is known as 'Tree of Life'. Papaya also has different names in different regions, i.e. Papaya in Northern America, Papaya/pawpaw/papaw in United Kingdom, Pawpaw/papaw in Africa and Pawpaw in Australia (Usman et al. 2015). Papaya provides lots of benefits for human health, including reducing cholesterol, improving digestion to help in weight loss, benefiting diabetic patient and preventing arthritis or cancer (Usman et al. 2015; Zuhair et al. 2013). This tropical non-seasonal fruit is easily available in Malaysia throughout the year, which makes its supply abundant and low in cost. However, papaya is a highly perishable fruit, where overripe papayas are usually discarded and causes high wastage. In order to avoid wastage, this research was carried out to look into the feasibility of converting the waste material into a functional beverage with health benefits. This research aimed to minimise the wastage by using excess papaya fruits in the market to produce vinegar-like fermented papaya beverage. The chemical changes throughout the fermentation process were analysed and the acetous fermentation would be optimised to produce the vinegar-like beverage.

\section{MATERIALS AND METHODS}

\section{MATERIALS}

Ripe Papaya fruit (Carica papaya) at the 6th stage of ripeness based on the visual characteristics as stated in Basulto et al. (2009) was purchased from a grocery store at Bangi, Selangor, Malaysia. Starter culture used for papaya juice alcoholic fermentation was yeast (Saccharomyces cerevisiae) from Mauri-Pan Instant Yeast, produced by AB Mauri Malaysia Sdn Bhd, Selangor, Malaysia. Bragg's apple cider vinegar which consisted mother of vinegar was used in acetous fermentation. This apple cider vinegar was a product from Bragg Live Foods, Inc., Santa Barbara, California, United States of America, that was supplied by CareMark Sdn Bhd, Petaling Jaya, Selangor, Malaysia

\section{PRODUCTION OF VINEGAR-LIKE FERMENTED} PAPAYA BEVERAGE

Preparation of papaya juice Papaya fruit was washed, peeled, cut and processed to become juice by mechanical extraction using juice extractor. Papaya juice was separated from the mass by centrifuging at $5000 \mathrm{rpm}$ for $10 \mathrm{~min}$ to separate the waste pulp and juice (Vithlani \& Patel 2010).
${ }^{\circ}$ Brix value of papaya juice was adjusted to $12 \%$ by adding glucose (Lee et al. 2010). Papaya juice was then pasteurised at $72^{\circ} \mathrm{C}$ for $15 \mathrm{~s}$ prior to the fermentation process.

Alcoholic fermentation of papaya juice Alcoholic fermentation was performed on the pasteurised papaya juice. Dry powdered yeast (S.cerevisiae) $(1.5 \mathrm{~g}$ ) was added into $150 \mathrm{~mL}$ of papaya juice in a $1000 \mathrm{~mL}$ Erlenmeyer flask and covered with cotton and parafilm to create anaerobic conditions for the alcoholic fermentation to occur, thus producing papaya wine (Delfini \& Formica 2001). Papaya juice sample was incubated in incubator shaker at $30^{\circ} \mathrm{C}$ for 7 days (Budak et al. 2014). Sampling was performed in alternate days throughout fermentation process (day 1 , 4 and 7). After each sampling, papaya wine sample was vortexed at $5000 \mathrm{rpm}$ for $10 \mathrm{~min}$ (Vithlani \& Patel 2010) to remove the yeast cells. The supernatant (papaya wine), was used for the subsequent acetous fermentation.

Optimisation of Acetous fermentation Optimisation of acetous fermentation was carried out using the response surface methodology (RSM) with central composite rotatable design (CCRD). Papaya wine sample after 7 days of alcohol fermentation was added with mother of vinegar (organic Bragg's apple cider vinegar) into a 100 $\mathrm{mL}$ Erlenmeyer flask and incubated at $30^{\circ} \mathrm{C}$ in a incubator shaker (IKA KS 4000) with speed of $180 \mathrm{rpm}$ (Ho et al. 2017b). The flasks were covered with cotton wool, but not sealed, to ensure aerobic conditions for acetous fermentation to occur. In the CCRD design, two factors were optimised, which were fermentation time $\left(\mathrm{T}_{\mathrm{f}}\right)$ with factor levels of $20.6 \mathrm{~h}(-1.414 \alpha), 60 \mathrm{~h}(-\alpha), 155 \mathrm{~h}(0)$, $250 \mathrm{~h}(\alpha)$ and $290 \mathrm{~h}(1.414 \alpha)$; and the mother of vinegar concentration $\left(\mathrm{C}_{\mathrm{mv}}\right)$ in relation to papaya wine $(\mathrm{v} / \mathrm{v})$ with factor levels of $16 \% \mathrm{v} / \mathrm{v}(-1.414 \alpha), 20 \% \mathrm{v} / \mathrm{v}(-\alpha), 30 \% \mathrm{v} / \mathrm{v}$ $(0), 40 \% \mathrm{v} / \mathrm{v}(\alpha)$ and $44 \% \mathrm{v} / \mathrm{v}(1.414 \alpha)$, as shown in Table 2 . The total volume for both papaya wine and mother of vinegar was $20 \mathrm{~mL}$ (eg. 30\% v/v = $6 \mathrm{~mL}$ mother of vinegar in $14 \mathrm{~mL}$ papaya wine). Optimisation was carried out using Design Expert software (version 6.0.10), in which the optimum point was determined through regression analysis by minimising the ethanol content, while maximising the acetic acid content. Other responses (reducing sugar, total phenolic content, ascorbic acid content and DPPH radical scavenging activity) were determined within the range. The papaya juice, pasteurised juice, papaya wine and vinegarlike fermented papaya beverage were stored at $4^{\circ} \mathrm{C}$ prior to further analyses (reducing sugar content, ethanol content, acetic acid content, total phenolic content, ascorbic acid content and DPPH radical scavenging activity).

\section{REDUCING SUGAR CONTENT ANALYSIS}

Reducing sugar content was determined using the dinitrosalicylic acid (DNS) method. DNS reagent was prepared by mixing $10 \mathrm{~g}$ dinitrosalicylic acid (DNS) and $300 \mathrm{~g}$ sodium potassium tartrate (Rochelle salt) into 800 $\mathrm{mL} 0.5 \mathrm{~N}$ sodium hydroxide and then it was warmed 
slowly and added with distilled water until it reached $1 \mathrm{~L}$. Sample (1 mL) was mixed with $4 \mathrm{~mL}$ DNS reagent inside a test tube placed in boiling water for $5 \mathrm{~min}$ and was then allowed to cool to room temperature. Absorbance at 540 $\mathrm{nm}$ was measured using a microplate spectrophotometer (Epoch BioTek) (Wood \& Bhat 1988). Calibration curve was prepared by following the same procedure as above, by replacing sample with glucose at concentration $0-0.01 \%$. Reducing sugar content of samples were calculated using the following equation:

$$
\text { Reducing sugar content }(\%)=\mathrm{R} \times \mathrm{DF} \times 100 \%
$$

where $\mathrm{R}$ is obtained from calibration curve and DF is dilution factor.

\section{ETHANOL CONTENT ANALYSIS}

Ethanol content in samples was analysed using dichromate method. Sample $(1 \mathrm{~mL})$ was mixed with $5 \mathrm{~mL}$ sodium dichromate solution $(40 \mathrm{mg} / \mathrm{mL}), 5 \mathrm{~mL}$ acetate buffer (pH4.3) and $25 \mathrm{~mL}$ solution $1 \mathrm{~N}$ sulphuric acid in $50 \mathrm{~mL}$ volumetric flask. Mixture was swirled slowly for $1 \mathrm{~min}$ and stored for $2 \mathrm{~h}$ at room temperature until green coloured product formed. Absorption at $578 \mathrm{~nm}$ was measured using microplate spectrophotometer (Epoch BioTek). Same procedure was repeated using ethanol standard solution (0-20\%) as calibration curve. Concentration of ethanol in samples determine using the calibration curve.

\section{ACETIC ACID CONTENT ANALYSIS}

Acetic acid content in samples was measured as total titratable acidity. Sample ( $1 \mathrm{~mL}$ ) was pipetted into $20 \mathrm{~mL}$ of deionised water in $50 \mathrm{~mL}$ Erlenmeyer flask. Approximately 3 drops of phenolphthalein indicator were added. Flask content was titrated with $0.1 \mathrm{~N}$ sodium hydroxide solutions until end point. Sample was replaced with $20 \mathrm{~mL}$ deionised water for blank titration performed by repeating the same procedure. Total titratable acidity content was calculated using the following equation (Cardwell et al. 1991):

$$
\begin{aligned}
& \text { Total titratable } \\
& \text { acidity } \%(\mathrm{w} / \mathrm{v})
\end{aligned}=\frac{\left(\mathrm{N}_{\mathrm{NaOH}}\right)\left(\mathrm{V}_{\mathrm{NaOH}}\right)\left(\mathrm{MW}_{\text {acetic acid }}\right)}{\mathrm{V}_{\text {sample }} \times 10}
$$

where $\mathrm{N}_{\mathrm{NaOH}}$ is $\mathrm{NaOH}$ concentration ( $\mathrm{mEq} / \mathrm{mL}$ ); $\mathrm{V}_{\mathrm{NaOH}}$ is $\mathrm{NaOH}$ volume $(\mathrm{mL}) ; \mathrm{MW}_{\text {acetic acid }}$ is acetic acid molecular weight $(60.05 \mathrm{mg} / \mathrm{mEq})$; and $\mathrm{V}_{\text {sample }}$ is sample volume $(\mathrm{mL})$.

\section{TOTAL PHENOLIC CONTENT ANALYSIS}

Folin-Ciocalteu method based on Mohd Fadzelly et al. (2015) was performed to determine total phenolic content in samples. Amount of $0.3 \mathrm{~mL}$ sample was mixed with $1.5 \mathrm{~mL}$ of $10 \%$ Folin-Ciocalteu reagent in test tube. After $5 \mathrm{~min}, 1.2 \mathrm{~mL}$ sodium carbonate solution of $7.5 \%(\mathrm{w} / \mathrm{v})$ was added into the test tube and vortex test tubes. The test tubes were then closed and stored for $30 \mathrm{~min}$ at room temperature. Absorbance was measured using microplate spectrophotometer (Epoch BioTek) at $765 \mathrm{~nm}$. Same procedure was repeated with gallic acid standard solution (0-100 mg/L) and calibration curve was interpreted. Total phenolic content in sample was calculated as gallic acid content equivalent $(\mathrm{mg}$ ) per L sample (mg GAE/L sample) using following equation (Lim et al. 2014):

$$
\text { Total phenolic }(\mathrm{mg} \mathrm{GAE} / \mathrm{mL} \text { sample })=\mathrm{R} \times \mathrm{DF}
$$

where $\mathrm{R}$ is reading from calibration line $(\mathrm{mg} / \mathrm{L})$ and $\mathrm{DF}$ is dilution factor.

\section{FREE-RADICAL SCAVENGING ACTIVITY ANALYSIS}

Sample $(1 \mathrm{~mL})$ was mixed with $2.9 \mathrm{~mL}$ methanolic $0.15 \mathrm{mM}$ DPPH. Mixture was stored in dark for $30 \mathrm{~min}$. Absorbance was measured at $517 \mathrm{~nm}$ inside 96-well plate $(200 \mu \mathrm{L})$ using microplate spectrophotometer (Epoch BioTek) (Ho et al. 2016). A blank was prepared by replacing sample with distilled water. Percentage of free-radical scavenging was measured using following equation:

$$
\begin{aligned}
& \% \text { Free-radical } \\
& \text { scavenging activity }
\end{aligned}=[(\mathrm{A} 1-\mathrm{A} 2) / \mathrm{A} 1] \times 100
$$

where A1 is blank absorbance and A2 is sample absorbance.

Same procedure was repeated using ascorbic acid standard solution $(0-50 \mathrm{mg} / \mathrm{L})$ and calibration line was interpreted. Free-radical scavenging activity was explained as ascorbic acid equivalent antioxidant capacity (AEAC) per $100 \mathrm{~g}$ sample (mg AA/100 g) using following equation (Lim et al. 2014):

$$
\operatorname{AEAC}(\mathrm{mg} \mathrm{AA} / 100 \mathrm{~g})=\mathrm{IC}_{50(\mathrm{AA})} / \mathrm{IC}_{50 \text { (sampel) }} \times 100,000
$$

where $\mathrm{AA}$ is ascorbic acid and $\mathrm{IC}_{50}$ is concentration of inhibition at $50 \%$.

\section{ASCORBIC ACID CONTENT ANALYSIS}

Ascorbic acid content in samples was analysed using indophenol method. Amount of $2 \mathrm{~mL}$ ascorbic acid standard solution $(1 \mathrm{mg} / \mathrm{mL})$ was pipetted into three $50 \mathrm{~mL}$ Erlenmeyer flasks which contained $5 \mathrm{~mL}$ of $3 \%$ metaphosphoric acid-acetic acid solution. Ascorbic acid standard solution was titrated with indophenol indicator until end point. Total volume indicator needed was recorded. Amount of $2 \mathrm{~mL}$ water was mixed with $5.0 \mathrm{~mL}$ of metaphosphoric acid-acetic acid solution for blank titration. Total volume indophenol indicator needed for blank titration was recorded and indicator factor was calculated using following equation:

$\begin{aligned} & \text { Indicator factor (mg ascorbic } \\ & \text { acid } / \mathrm{mL} \text { of indicator) }\end{aligned}=\frac{\mathrm{W}}{\mathrm{V}_{\mathrm{s}}-\mathrm{V}_{\mathrm{o}}}$ 
where $\mathrm{W}$ is weight of ascorbic acid used $(\mathrm{mg}) ; \mathrm{V}_{\mathrm{s}}$ is volume of indicator used in standard solution titration (mL); and $\mathrm{V}_{\text {。 }}$ is volume of indicator used in blank titration $(\mathrm{mL})$.

Amount of $5 \mathrm{~mL}$ of $3 \%$ metaphosphoric acid-acetic acid was pipetted into three $50 \mathrm{~mL}$ Erlenmeyer flasks, followed with $2 \mathrm{~mL}$ sample. Sample was titrated with indophenol indicator until endpoint. Total volume of indicator used was determined with vitamin C content calculation using following equation (Kumar et al. 2013):

$$
\underset{(\mathrm{mg} / 100 \mathrm{~mL} \text { sample })}{\text { Vitamin } \mathrm{C} \text { content }}=\frac{\mathrm{F} \times\left(\mathrm{V}-\mathrm{V}_{0)}\right.}{\mathrm{SV}} \times 100
$$

where $\mathrm{F}$ is indicator factor ( $\mathrm{mg}$ ascorbic acid/mL indicator); $\mathrm{V}_{0}$ is average volume of indicator used in blank titration $(\mathrm{mL}) ; \mathrm{V}$ is average volume of indicator used in sample titration $(\mathrm{mL})$ and $\mathrm{SV}$ is sample volume $(\mathrm{mL})$.

\section{VERIFICATION OF OPTIMUM POINT}

Optimum points of acetous fermentation were at $\mathrm{T}_{\mathrm{f}}=70.80$ $\mathrm{h}$ and $\mathrm{C}_{\mathrm{mv}}=40 \% \mathrm{v} / \mathrm{v}$ mother of vinegar. A new batch of acetous fermentation was carried out at these optimum points as verification test. All chemical analyses were repeated on the new sample batch and comparison was also performed with the apple cider mother of vinegar. In the verification of optimum point, experimental values and predicted values of the sample were compared to examine model's validity.

\section{STATISTICAL ANALYSIS}

All chemical analysis was performed in triplicate $(n=3)$. Variance analysis (ANOVA) and Fisher's Least Significance Difference test (LSD) at confidence level of 95\% $(p<0.05)$ were used to determine statistical significance between factors and treatments, using Minitab Version 16. Response surface methodology with CCRD design was performed on acetous fermentation using Design Expert software, version 6.0.10.

\section{RESULTS AND DISCUSSION}

\section{PRODUCTION OF VINEGAR-LIKE FERMENTED PAPAYA BEVERAGE}

Pasteurisation was performed to avoid spoilage of sample before and during fermentation process. The results in Table 1 shows that pasteurisation of papaya juice caused the increase of reducing sugar content and total phenolic content significantly $(p<0.05)$ whereas it reduced ascorbic acid content and free-radical scavenging activity significantly $(p<0.05)$. Ethanol content and acetic acid content in papaya juice were not affected by heat of pasteurisation. The increase in reducing sugar content is due to the hydrolysis of polysaccharides present in the papaya juice, such as pectins, cellulose and starch, into reducing sugars (Bal et al. 2014). Randhir et al. (2008) reported that heat treatment could increase the phenolic contents, due to the release of phenolic compounds bound to cell wall materials. The significant reduction of ascorbic acid and free-radical scavenging activity in the pasteurised juice is due to its destruction when heat treatment was applied (Van Den Broeck et al. 1998).

The metabolic changes in alcoholic fermentation is as showed in Figure 1. During alcoholic fermentation, it was found that reducing sugar content reduced significantly $(p<0.05)$ whereas ethanol content increased significantly $(p<0.05)$ due to the conversion of sugar to ethanol by yeast (Ho et al. 2017a). Acetic acid and ascorbic acid contents also significantly increased $(p<0.05)$ during alcoholic fermentation, from $0.12 \%$ in Day 0 to $0.72 \%$ in Day 7 for acetic acid and $0.59 \mathrm{mg} / 100 \mathrm{~mL}$ in Day 0 to 14.90 $\mathrm{mg} / 100 \mathrm{~mL}$ in Day 7 for ascorbic acid. Yeast has been reported to produce small amount of acids, such as acetic

TABLE 1. Content of reducing sugar, ethanol, acetic acid, total phenolic and ascorbic acid in fresh juice and pasteurised juice $(n=3)$

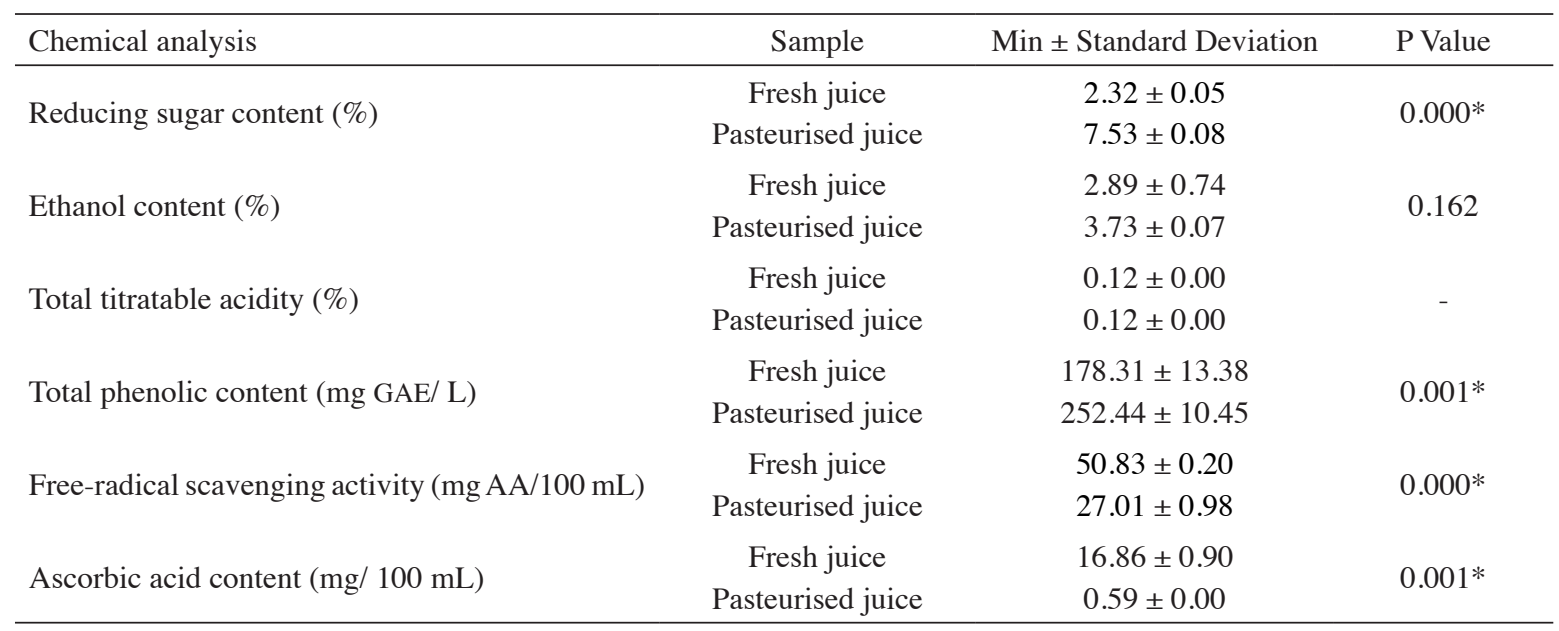

*shown as significance difference at $(p<0.05)$ 


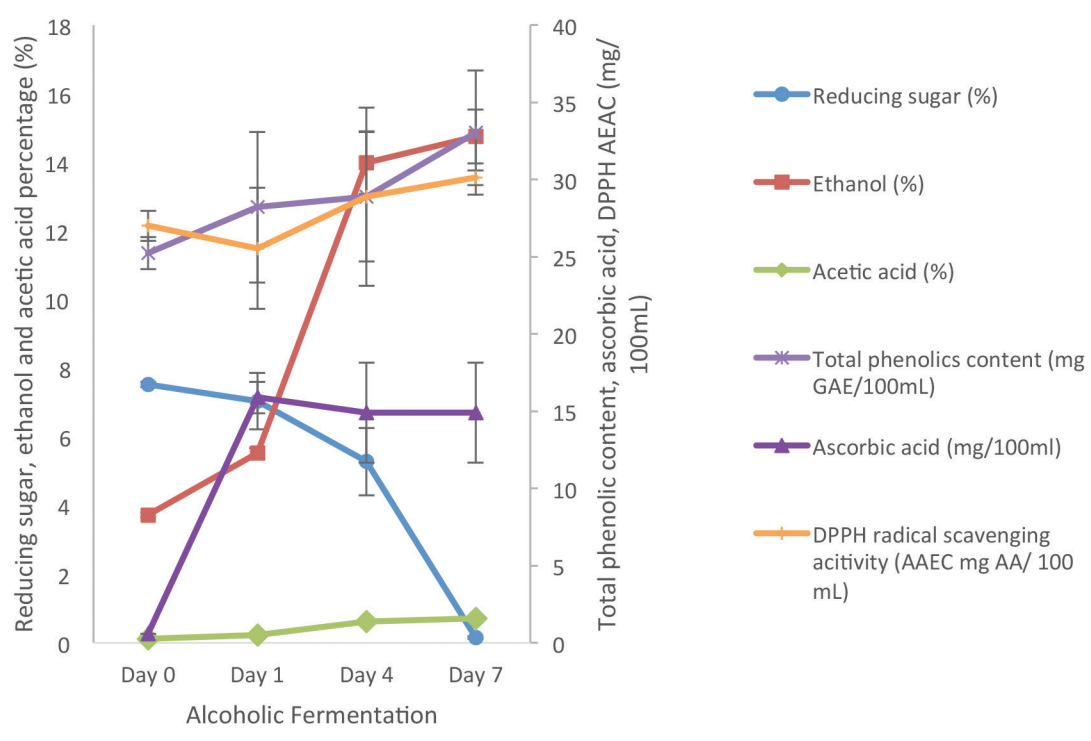

FIGURE 1. Changes of reducing sugar, ethanol, acetic acid, ascorbic acid, total phenolic content and DPPH AEAC during alcoholic fermentation

acid, succinic acid and pyruvic acid as by-products, as response to hyperosmosis stress due to the high amount of sugar (Chidi et al. 2015; Dubourdieu et al. 2005; Erasmus et al. 2004; Ferreira et al. 2006). Alcoholic fermentation did not significantly $(p>0.05)$ affect total phenolic content and DPPH free-radical scavenging activity as phenolic compound originally from papaya juice was retained in the papaya wine (Nogueira et al. 2008) and antioxidative activity of sample was not affected by alcoholic fermentation process (Pérez-Gregorio et al. 2011).

The optimisation of acetous fermentation was performed and the response surfaces and models are shown in Figure $2 . T_{f}$ significantly affected $(p<0.05)$ reducing sugar content whereas $\mathrm{C}_{\mathrm{mv}}$ did not significantly $(p>0.05)$ affect reducing sugar content after acetous fermentation based on Table 2. The reducing sugar content in samples increased along with $T_{f}$ during acetous fermentation because more non-reducing sugar had converted to reducing sugar in acidic condition. Sucrose could be hydrolysed by invertase from $S$. cerevisiae, acid or heat (Cheeke \& Dierenfeld 2010). Therefore, longer $T_{f}$ caused higher reducing sugar content in the vinegar-like fermented papaya beverage as shown in Figure 2(a).

Higher $\mathrm{T}_{\mathrm{f}}$ also showed significant effect $(p<0.05)$ for ethanol content, while mother of vinegar concentration $\left(\mathrm{C}_{\mathrm{mv}}\right)$ showed no significant effect $(p>0.05)$ towards ethanol content after acetous fermentation based on Table 2. Acetous fermentation that involved aerobic oxidation of ethanol to become acetic acid by acetic acid bacteria (Emde 2014; Ho et al. 2017a) caused ethanol content decreased. Besides, there are also ethanol losses due to evaporation during fermentation (Caro et al. 1992). Therefore, longer acetous $\mathrm{T}_{\mathrm{f}}$ caused lower ethanol content in sample as shown in Figure 2(b).

Moreover, coefficient analysis was performed for acetic acid content and result showed that $\mathrm{T}_{\mathrm{f}}$ had significant effect $(p<0.05)$ for acetic acid content whereas $\mathrm{C}_{\mathrm{mv}}$ had no significant effect $(p>0.05)$ for acetic acid content after acetous fermentation based on Table 2. It was found that the acetic acid content increased initially, but it reduces over time, as shown in Figure 2(c). Acetic acid is a compound that evaporates easily. This influenced loss of acetic acid through evaporation when exposed to air (Sanarico et al. 2003). Therefore, longer $\mathrm{T}_{\mathrm{f}}$ caused higher amount of acetic acid evaporated.

$\mathrm{T}_{\mathrm{f}}$ gave significant effect $(p<0.05)$ for total phenolic content, whereas $\mathrm{C}_{\mathrm{mv}}$ gave no significant effect $(p>0.05)$ for total phenolic content after acetous fermentation based on Figure 2(d) and Table 2. Oxidation and other factors could influence total phenolic content during acetification process (Su \& Chien 2007).

$\mathrm{T}_{\mathrm{f}}$ affected significantly $(p<0.05)$ on ascorbic acid content while $\mathrm{C}_{\mathrm{mv}}$ did not significantly $(p>0.05)$ affect the ascorbic acid content based on Table 2. The main factors for ascorbic acid losses were heating process and oxidation (Lešková et al. 2006). Erlenmeyer flask which contained sample was not closed throughout period of fermentation process due to acetous fermentation requires aerobic conditions. Hence, oxidation of ascorbic acid occurred, causing ascorbic acid content in sample to decrease over time, as shown in Figure 2(e). Longer $T_{f}$ caused more ascorbic acid to be oxidised.

$\mathrm{T}_{\mathrm{f}}$ also affected significantly $(p<0.05)$ on DPPH free-radical scavenging activity whereas $\mathrm{C}_{\mathrm{mv}}$ did not significantly $(p>0.05)$ affect the DPPH free-radical scavenging activity after acetous fermentation, as shown in Figure 2(f) and Table 2. When compared with the antioxidant compounds present in the samples, i.e. phenolics and ascorbic acid, it was found that the DPPH free-radical scavenging activity were consistent with the ascorbic acid contents, where both reduces over time. Hence, longer $T_{f}$ caused lower free-radical scavenging 
(a)

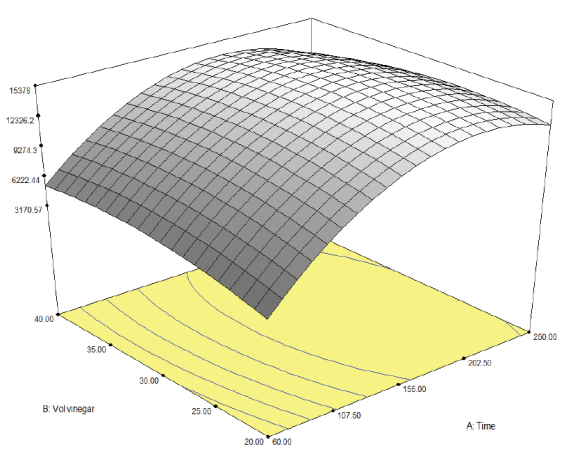

Reducing sugar $=14570.00+4020.44 * \mathrm{~A}+$ $144.19 * \mathrm{~B}-5055.94 \mathrm{~A}^{2}-1278.85 * \mathrm{~B}^{2}-900.00 * \mathrm{AB}$

(c)

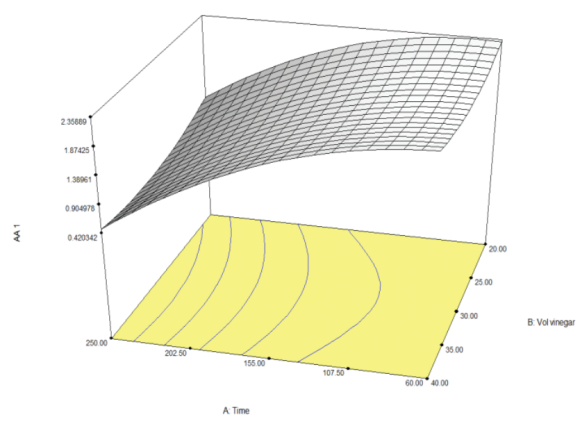

Acetic acid $=1.74-0.84 * \mathrm{~A}-0.079 * \mathrm{~B}-0.45^{*} \mathrm{~A}^{2}$ $+0.21 * \mathrm{~B}^{2}-0.10 * \mathrm{AB}$

(e)

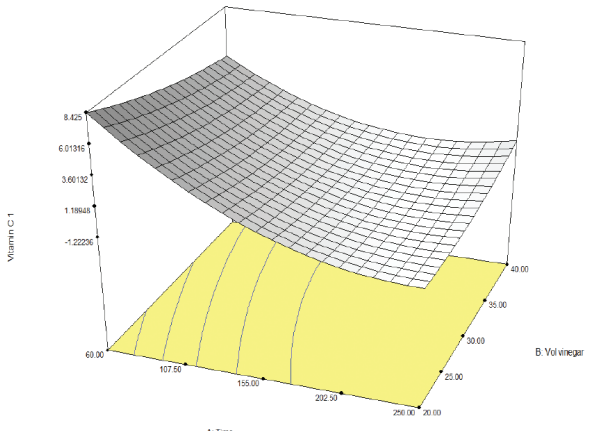

Ascorbic acid $=-3.38 * \mathrm{~A}-0.69 * \mathrm{~B}+2.43 * \mathrm{~A}^{2}+$ $0.56 * \mathrm{~B}^{2}+1.37 * \mathrm{AB}$ (b)

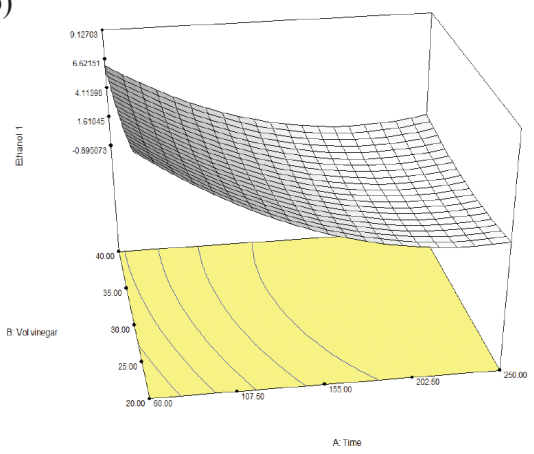

Ethanol $=0.35-3.71 * \mathrm{~A}-0.75 * \mathrm{~B}+2.79 * \mathrm{~A}^{2}+$ $0.75 * \mathrm{~B}^{2}+0.76 * \mathrm{AB}$

(d)

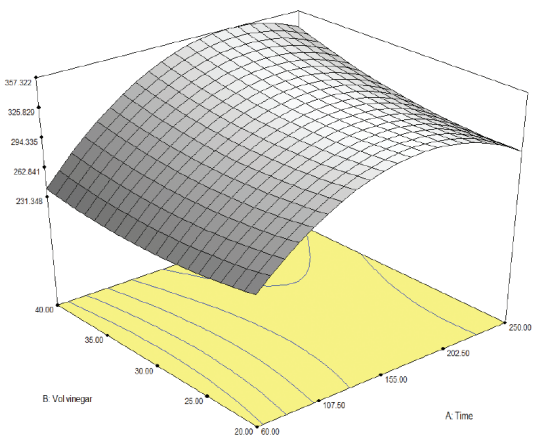

$\mathrm{TPC}=325.37+37.64 * \mathrm{~A}+9.10 * \mathrm{~B}-56.18 * \mathrm{~A}^{2}+$ $11.85 * \mathrm{~B}^{2}+12.31 * \mathrm{AB}$

(f)

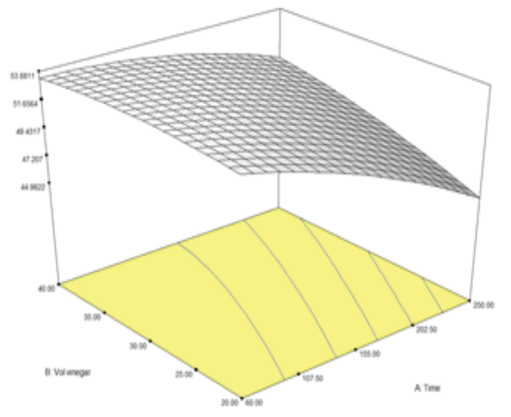

DPPH AEAC $=51.78-2.98 * \mathrm{~A}+1.21 * \mathrm{~B}-0.88 * \mathrm{~A}^{2}$ $-0.53 * \mathrm{~B}^{2}+1.20 * \mathrm{AB}$

FIGURE 2. Response surfaces and models of fermentation time (factor A) and mother of vinegar concentration (factor B) towards (a) reducing sugar content, (b) ethanol content, (c) acetic acid content, (d) total phenolic content, (e) ascorbic acid content and (f) DPPH radical scavenging activity (AEAC) in acetous fermentation samples

activity in vinegar-like fermented papaya beverage sample.

\section{VERIFICATION OF OPTIMUM POINT}

Optimum points of acetous fermentation were obtained from Design Expert Software where the optimised conditions for acetous fermentation are $T_{f}=70.80 \mathrm{~h}$ and $\mathrm{C}_{\mathrm{mv}}=40 \%$ mother of vinegar. The predicted values for each analysis were compared to the experimental value to determine validity of experimental design using response surface methodology (RSM). Table 3 shows the difference of reducing sugar, ethanol, acetic acid, total phenolic, ascorbic acid content and free-radical scavenging activity between the vinegar-like fermented papaya beverage sample produced in verification process of acetous fermentation and mother of vinegar (organic Bragg's apple cider vinegar) and predicted values from RSM model. The produced vinegar-like fermented papaya beverage has $2.46 \pm 0.07 \%$ acetic acid content, which is less than the requirement of $4 \%$ acetic acid content to be labelled as vinegar. Therefore, the produced 
TABLE 2. Content of sugar, ethanol, acetic acid, total phenolic, free radical scavenging activity and ascorbic acid in 13 runs through CCRD design for acetous fermentation

\begin{tabular}{ccccccccc}
\hline Run & $\begin{array}{c}\text { Mother of } \\
\text { vinegar } \\
\text { concentration } \\
(\%)\end{array}$ & $\begin{array}{c}\text { Fermentation } \\
\text { time (h) }\end{array}$ & $\begin{array}{c}\text { Sugar } \\
\text { content } \\
(\%)\end{array}$ & $\begin{array}{c}\text { Ethanol } \\
\text { content }(\%)\end{array}$ & $\begin{array}{c}\text { Acetic acid } \\
\text { content }(\%)\end{array}$ & $\begin{array}{c}\text { Total phenolic } \\
\text { content } \\
(\mathrm{mg} \text { GAE/L) }\end{array}$ & $\begin{array}{c}\text { Free radical } \\
\text { scavenging } \\
\text { activity }(\mathrm{mg} \\
\text { AA/100 mL) }\end{array}$ & $\begin{array}{c}\text { Ascorbic } \\
\text { acid content } \\
(\mathrm{mg} / 100 \mathrm{~mL})\end{array}$ \\
\hline 1 & 30 & 20.6 & 0.13 & 9.63 & 1.88 & 191.2438 & 53.91 & 7.45 \\
2 & 20 & 60 & 0.15 & 10.93 & 2.02 & 224.5771 & 51.81 & 10.98 \\
3 & 40 & 60 & 0.22 & 6.98 & 2.78 & 207.1642 & 55.77 & 5.49 \\
4 & 16 & 155 & 1.29 & 1.47 & 2.92 & 346.4677 & 42.30 & 0.00 \\
5 & 30 & 155 & 1.48 & 0.74 & 1.82 & 332.0398 & 49.72 & 0.00 \\
6 & 30 & 155 & 1.59 & 0.00 & 1.58 & 275.3234 & 52.01 & 0.00 \\
7 & 30 & 155 & 1.38 & 0.20 & 1.56 & 349.9502 & 49.89 & 0.00 \\
8 & 30 & 155 & 1.44 & 0.32 & 1.56 & 325.5721 & 47.96 & 0.00 \\
9 & 30 & 155 & 1.39 & 0.51 & 2.18 & 343.9801 & 51.06 & 0.00 \\
10 & 44 & 155 & 1.51 & 0.66 & 1.68 & 387.7612 & 52.37 & 0.00 \\
11 & 20 & 250 & 1.20 & 0.89 & 0.12 & 294.2289 & 54.17 & 0.00 \\
12 & 40 & 250 & 0.92 & 0.00 & 0.48 & 326.0697 & 54.69 & 0.00 \\
13 & 30 & 290 & 1.16 & 0.66 & 0.12 & 270.8458 & 46.09 & 0.00 \\
\hline
\end{tabular}

beverage is termed as the vinegar-like fermented papaya beverage. The vinegar-like fermented papaya beverage sample showed significantly lower $(p<0.05)$ reducing sugar concentration and ascorbic acid amount, while total phenolic content was significantly higher $(p<0.05)$ compared with predicted values. Optimum point to produce vinegar-like fermented papaya beverage that contained lower sugar content compared with predicted values was an acceptable deviation. The reason was acetic acid formed through changing of sugar to alcohol by yeast and from alcohol to acetic acid by acetic acid bacteria and thus, the lower sugar content is due to the production of higher acetic acid. The vinegar-like fermented papaya beverage contained significantly $(p<0.05)$ higher total phenolic content compared with predicted value because acetification could increase phenolic compound content in sample (Kongkiattikajor 2015). There were no significant differences $(p<0.05)$ between the vinegar-like fermented papaya beverage and predicted values from ethanol content, acetic acid and free-radical scavenging activity. This showed the validity of optimum point and the RSM model.

The vinegar-like fermented papaya beverage sample and Bragg's apple cider mother of vinegar contained concentration of reducing sugar, acetic acid, total phenolic, ascorbic acid and free-radical scavenging activity with significant difference $(p<0.05)$. Bragg's apple cider mother of vinegar contained significantly $(p<0.05)$ higher acetic acid content, total phenolic, ascorbic acid and free-radical scavenging activity than the vinegar-like fermented papaya beverage. Ethanol content of both samples were not significantly different $(p>0.05)$ between the vinegar-like fermented papaya beverage and Bragg's apple cider mother of vinegar. Overall, this proves that the vinegar-like fermented papaya beverage produced were similar to the statistically predicted values, but were different when compared to the commercial vinegar (Bragg's apple cider mother of vinegar).

TABLE 3. Chemical composition and antioxidant activities of vinegar-like fermented papaya beverage sample, apple mother of vinegar and predicted values from RSM model

\begin{tabular}{lccc}
\hline Chemical analysis & Predicted value & $\begin{array}{c}\text { Experimental value } \\
\text { (Vinegar-like fermented } \\
\text { papaya beverage) }\end{array}$ & $\begin{array}{c}\text { Bragg's apple cider } \\
\text { mother of vinegar }\end{array}$ \\
\hline Reducing Sugar (\%) & $0.67^{\mathrm{a}}$ & $0.37 \pm 0.01^{\mathrm{b}}$ & $0.27^{\mathrm{a}} \pm 0.01^{\mathrm{c}}$ \\
Ethanol (\%) & $5.18^{\mathrm{a}}$ & $3.54 \pm 0.36^{\mathrm{a}}$ & $2.92 \pm 1.83^{\mathrm{a}}$ \\
Acetic Acid (\%) & $2.35^{\mathrm{b}}$ & $2.46 \pm 0.07 \mathrm{~b}$ & $4.82^{\mathrm{b}} \pm 0.03^{\mathrm{a}}$ \\
Total Phenolic (mg GAE/ L) & $257.881^{\mathrm{c}}$ & $327.89 \pm 3.60^{\mathrm{b}}$ & $407.66 \pm 2.99^{\mathrm{a}}$ \\
Free-radical Scavenging Activity (mg AA/ 100 mL) & $53.35^{\mathrm{ab}}$ & $52.40 \pm 0.23^{\mathrm{b}}$ & $55.11 \pm 0.77^{\mathrm{a}}$ \\
Ascorbic Acid (mg/ 100 mL) & $3.56^{\mathrm{b}}$ & $2.32 \pm 0.17^{\mathrm{c}}$ & $14.31 \pm 0.34^{\mathrm{a}}$ \\
\hline
\end{tabular}

${ }^{a-c}$ different alphabets in the same row showed significant difference $(\mathrm{p}<0.05)$ 


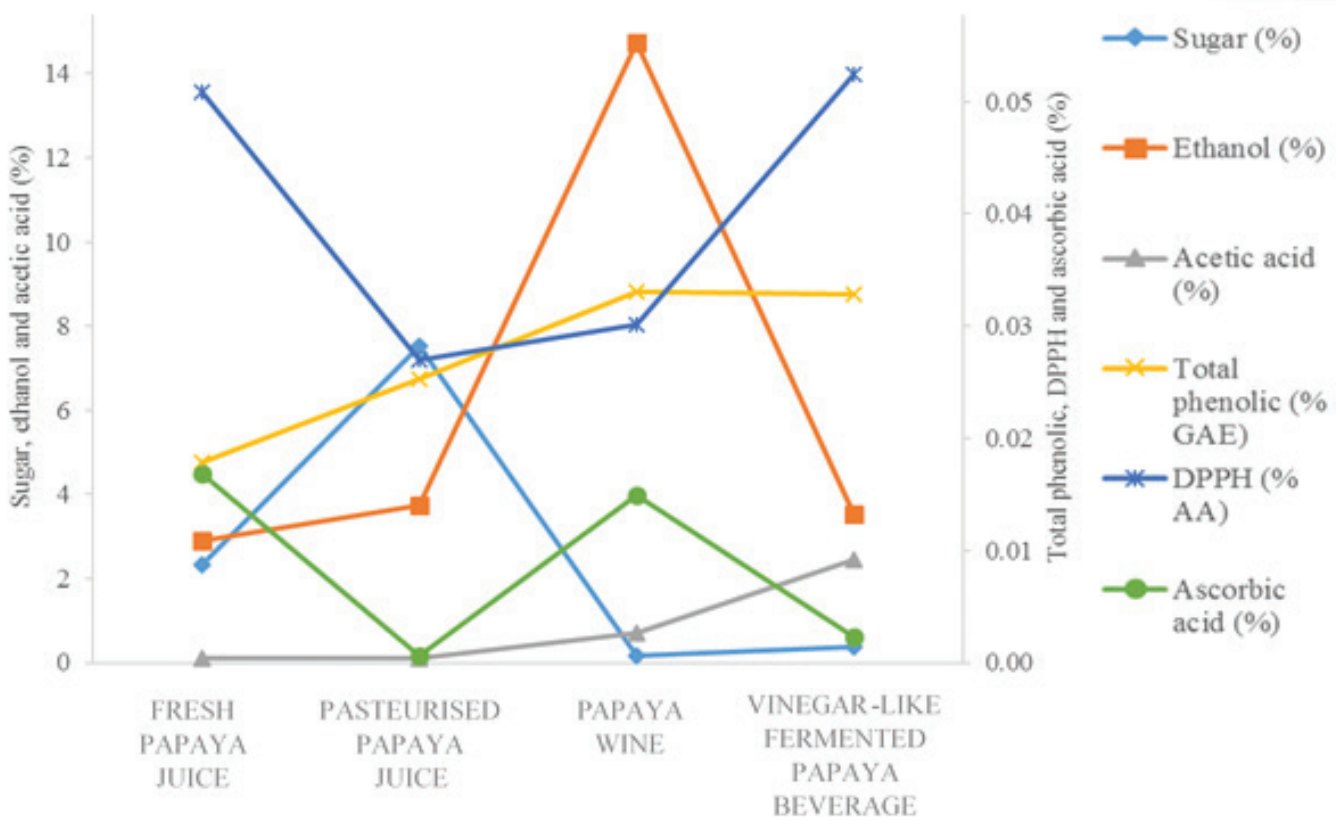

FIGURE 3. Chemical composition changes from papaya juice to wine and vinegar-like fermented papaya beverage

CHANGES OF CHEMICAL COMPOSITION FROM PAPAYA JUICE TO VINEGAR-LIKE FERMENTED PAPAYA BEVERAGE

Figure 3 shows overall changes of chemical composition throughout the vinegar-like fermented papaya beverage production process, i.e. from papaya juice to pasteurised juice to wine and the vinegar-like beverage. Pasteurisation caused reducing sugar and total phenolic contents in papaya juice increased whereas ascorbic acid content and free-radical scavenging activity in papaya juice decreased. Increased reducing sugar content was caused by polysaccharide hydrolysis (Bal et al. 2014). Phenolic acid production was related to cellular constituent and cell wall disruption due to heat processing that caused total phenolic content to increase (Chism \& Haard 1996). Ascorbic acid content decreased because of oxidation (Lešková et al. 2006). Ethanol and acetic acid contents in papaya juice were not influenced by heat processing. After 7 days of alcoholic fermentation, reducing sugar content decreased while ethanol content increased due to the conversion of sugar in pasteurised papaya juice to ethanol by yeast (Emde 2014). Acetic acid content in wine sample also increased. Besides, ascorbic acid content increased during alcoholic fermentation because yeast could produce antioxidant molecules, including D-erythroascorbic acid (Huh et al. 1998). There was no significant difference $(p>0.05)$ between juice sample and wine sample based on total phenolic content and free-radical scavenging activity.

In acetous fermentation process, acetic acid content increased and ethanol content decreased because ethanol was converted to acetic acid by Acetobacter spp (Emde 2014). Free-radical scavenging activity also increased during acetous fermentation. Ascorbic acid content in the vinegar-like fermented papaya beverage was lower compared to papaya wine due to ascorbic acid oxidation happened throughout period of acetous fermentation which is in aerobic conditions (Lešková et al. 2006).

\section{CONCLUSION}

Vinegar-like fermented papaya beverage was successfully produced from papaya juice. Optimum fermentation time and mother of vinegar concentrations for producing the vinegar-like fermented papaya beverage were $70.80 \mathrm{~h}$ and $40 \%$ mother of vinegar. There was no significant difference $(p>0.05)$ between the vinegar-like fermented papaya beverage and predicted values from contents of ethanol, acetic acid and free-radical scavenging activity. This showed the validity of optimum point and RSM model. There was a significant change for chemical composition $(p<0.05)$ along the process of producing vinegar-like fermented papaya beverage from papaya juice. Overall, there is potential for production of vinegar-like beverages from tropical fruits, including papaya. This could reduce wastage by converting these highly-perishable fruits into functional food, including tropical fruit vinegar-like beverages.

\section{ACKNOWLEDGEMENTS}

This project was funded by INDUSTRI-2014-005 and GP-K020181 research grants provided by Universiti Kebangsaan Malaysia. The authors would like to acknowledge the Centre for Biotechnology and Functional Food, Faculty of Science and Technology, Universiti Kebangsaan Malaysia (UKM) for providing all the facilities and chemicals required for this research. 


\section{REFERENCES}

Akubor, P.I. 2017. Characterization of fruit wines from baobab (Adansonia digitata), pineapple (Ananas sativus) and carrot (Daucus carota) tropical fruits. Asian Journal of Biotechnology and Bioresource Technology 1(3): 1-10.

Bal, L., Ahmad, T., Senapati, A. \& Pandit, P. 2014. Evaluation of quality attributes during storage of guava nectar cv. Lalit from different pulp and TSS ratio. Journal of Food Processing and Technology 5: 329.

Basulto, F.S., Duch, E.S., Y-Gil, F.E., Diaz Plaza, R., Saavedra, A.L. \& Santamaria, J.M. 2009. Postharvest ripening and maturity indices for Maradol papaya. Interciencia 34(8): 583-588.

Budak, N.H., Aykin, E., Seydim, A.C., Greene, A.K. \& GuzelSeydim, Z.B. 2014. Functional properties of vinegar. Journal of Food Science 79(5): R757-R764.

Cardwell, T.J., Cattrall, R.W., Cross, G.J., O'connell, G.R., Petty, J.D. \& Scollary, G.R. 1991. Determination of titratable acidity of wines and total acidity of vinegars by discontinuous flow analysis using photometric end-point detection. Analyst 116(10): 1051-1054.

Caro, I., Pérez, L., Cantero, D. \& Webb, C. 1992. Modelling of ethanol evaporative losses during batch alcohol fermentation. The Chemical Engineering Journal 48(3): B15-B22.

Cheeke, P.R. \& Dierenfeld, E.S. 2010. Comparative Animal Nutrition and Metabolism. Oxfordshire: CABI.

Chidi, B., Rossouw, D., Buica, A. \& Bauer, F. 2015. Determining the impact of industrial wine yeast strains on organic acid production under white and red wine-like fermentation conditions. South African Journal of Enology and Viticulture 36(3): 316-327.

Chism, G.W. \& Haard, N.F. 1996. Characteristics of edible plant tissues. In Food Chemistry, edited by Fennema, O.R. New York: Marcel Dekker Inc. pp. 943-1011.

Coelho, E., Genisheva, Z., Oliveira, J.M., Teixeira, J.A. \& Domingues, L. 2017. Vinegar production from fruit concentrates: Effect on volatile composition and antioxidant activity. Journal of Food Science and Technology 54(12): 4112-4122.

Delfini, C. \& Formica, J.V. 2001. Wine Microbiology: Science and Technology. Philadelphia: Taylor \& Francis.

Dubourdieu, D., Masneuf, I. \& Bely, M. 2005. Influence of physiological state of inoculum on volatile acidity production by Saccharomyces cerevisiae during high sugar fermentation. International Journal of Vine and Wine Sciences 39(4): 191-198.

Emde, F. 2014. Ullmann's Encyclopedia of Industrial Chemistry: Vinegar. Weinheim: Wiley VCH Verlag $\mathrm{GmbH} \& \mathrm{Co}$.

Erasmus, D.J., Cliff, M. \& Van Vuuren, H.J. 2004. Impact of yeast strain on the production of acetic acid, glycerol, and the sensory attributes of icewine. American Journal of Enology and Viticulture 55(4): 371-378.

Fatima, B. \& Mishra, A. 2015. Optimization of process parameter for the production of vinegar from banana peel and coconut water. International Journal of Science, Engineering and Technology 3(3): 817-823.

Ferreira, J., Toit, M. \& Toit, W.D. 2006. The effects of copper and high sugar concentrations on growth, fermentation efficiency and volatile acidity production of different commercial wine yeast strains. Australian Journal of Grape and Wine Research 12(1): 50-56

Ho, C.W., Lazim, A.M., Fazry, S., Umi Kalsum, H.Z. \& Lim, S.J. 2017a. Varieties, production, composition and health benefits of vinegars: A review. Food Chemistry 221: 1621-1630.
Ho, C.W., Lazim, A.M., Fazry, S., Umi Kalsum, H.Z. \& Lim, S.J. 2017b. Effects of fermentation time and $\mathrm{pH}$ on soursop (Annona muricata) vinegar production towards its chemical compositions. Sains Malaysiana 46(9): 1505-1512.

Ho, Y.M., Wan Amir Nizam, W.A. \& Wan Rosli, W.I. 2016 Antioxidative activities and polyphenolic content of different varieties of malaysian young corn ear and cornsilk. Sains Malaysiana 45(2): 195-200.

Huh, W.K., Lee, B.H., Kim, S.T., Kim, Y.R., Rhie, G.E., Baek, Y.W., Hwang, C.S., Lee, J.S. \& Kang, S.O. 1998. D-Erythroascorbic acid is an important antioxidant molecule in Saccharomyces cerevisiae. Molecular Microbiology 30(4): 895-903.

Kongkiattikajor, J. 2015. Enhancement of bioactive compounds of roselle vinegar by co-culture fermentation. Isan Journal of Pharmaceutical Sciences 10(4): 61-74.

Kumar, G.V., Ajay Kumar, K., Raghu, P.G. \& Manjappa, S. 2013. Determination of vitamin $\mathrm{C}$ in some fruits and vegetables in Davanagere city, (Karanataka)-India. International Journal of Pharmacy \& Life Sciences 4(3): 2489-2491.

Lee, P.R., Ong, Y.L., Yu, B., Curran, P. \& Liu, S.Q. 2010. Profile of volatile compounds during papaya juice fermentation by a mixed culture of Saccharomyces cerevisiae and Williopsis saturnus. Food Microbiology 27(7): 853-861.

Lešková, E., Kubíková, J., Kováčiková, E., Košická, M., Porubská, J. \& Holčíková, K. 2006. Vitamin losses: Retention during heat treatment and continual changes expressed by mathematical models. Journal of Food Composition and Analysis 19(4): 252-276.

Lim, S.J., Wan Aida, W.M., Maskat, M.Y., Mamot, S., Ropien, J. \& Mohd, D.M. 2014. Isolation and antioxidant capacity of fucoidan from selected Malaysian seaweeds. Food Hydrocolloids 42: 280-288.

Lingham, T., Besong, S., Ozbay, G. \& Lee, J. 2012. Antimicrobial activity of vinegar on bacterial species isolated from retail and local channel catfish (Ictalurus punctatus). Journal of Food Processing and Technology S11-001 2: 25-28.

Malaysia Food Regulations. 1985. Regulation 334. Putrajaya: Ministry of Health, Malaysia.

Mohamad, N.E., Yeap, S.K., Lim, K.L., Mohd Yusof, H., Beh, B.K., Tan, S.W., Ho, W.Y., Sharifuddin, S.A., Jamaluddin, A., Long, K., Nik Abd Rahman, N.M.A. \& Alitheen, N.B. 2015. Antioxidant effects of pineapple vinegar in reversing of paracetamol-induced liver damage in mice. Chinese Medicine 10: 3 .

Mohd Fadzelly, A.B., Fifilyana, A.K. \& Perisamy, E. 2015 Comparison of phytochemicals and antioxidant properties of different fruit parts of selected artocarpus species from Sabah, Malaysia. Sains Malaysiana 44(3): 355-363.

Morales, L.M., González, G.A., Casas, J.A. \& Troncoso, A.M. 2001. Multivariate analysis of commercial and laboratory produced sherry wine vinegars: Influence of acetification and aging. European Food Research and Technology 212(6): 676-682.

Nogueira, A., Guyot, S., Marnet, N., Lequéré, J.M., Drilleau, J.F. \& Wosiacki, G. 2008. Effect of alcoholic fermentation in the content of phenolic compounds in cider processing. Brazilian Archives of Biology and Technology 51(5): 1025-1032.

Pérez-Gregorio, M.R., Regueiro, J., Alonso-González, E., Pastrana-Castro, L.M. \& Simal-Gándara, J. 2011. Influence of alcoholic fermentation process on antioxidant activity and phenolic levels from mulberries (Morus nigra L.). LWT - Food Science and Technology 44(8): 1793-1801. 
Randhir, R., Kwon, Y.I. \& Shetty, K. 2008. Effect of thermal processing on phenolics, antioxidant activity and healthrelevant functionality of select grain sprouts and seedlings. Innovative Food Science \& Emerging Technologies 9(3): 355-364.

Sanarico, D., Motta, S., Bertolini, L. \& Antonelli, A. 2003. HPLC determination of organic acids in traditional balsamic vinegar of Reggio emilia. Journal of Liquid Chromatography \& Related Technologies 26(13): 2177-2187.

Su, M.S. \& Chien, P.J. 2007. Antioxidant activity, anthocyanins, and phenolics of rabbiteye blueberry (Vaccinium ashei) fluid products as affected by fermentation. Food Chemistry 104(1): 182-187.

Usman, M., Davidson, J. \& Books, M.C. 2015. Health Benefits of Papaya - for Cooking and Healing. Mendon: Mendon Cottage Books.

Van Den Broeck, I., Ludikhuyze, L., Weemaes, C., Van Loey, A. \& Hendrickx, M. 1998. Kinetics for isobaric-isothermal degradation of 1-ascorbic acid. Journal of Agricultural and Food Chemistry 46(5): 2001-2006.

Vithlani, V.A. \& Patel, H.V. 2010. Production of functional vinegar from Indian jujube (Zizyphus mauritiana) and its antioxidant properties. Journal of Food Technology 8(3): 143-149.

Wood, T.M. \& Bhat, K.M. 1988. Methods for measuring cellulase activities. Methods in Enzymology 160: 87-112.

Zuhair, R.A., Aminah, A., Sahilah, A.M. \& Eqbal, D. 2013. Antioxidant activity and physicochemical properties changes of papaya (Carica papaya L. cv. Hongkong) during different ripening stage. International Food Research Journal 20(4): 1653-1659.
Ching Ting Kong, Chin Wai Ho, Jin Wei Alvin Ling \& Seng Joe Lim*

Centre for Biotechnology and Functional Food

Faculty of Science and Technology

Universiti Kebangsaan Malaysia

43600 UKM Bangi, Selangor Darul Ehsan

Malaysia

Azwan Lazim

Centre for Advanced Materials and Renewable Resources

Faculty of Science and Technology

Universiti Kebangsaan Malaysia

43600 UKM Bangi, Selangor Darul Ehsan

Malaysia

\section{Shazrul Fazry}

Tasik Chini Research Centre

Faculty of Science and Technology

Universiti Kebangsaan Malaysia

43600 UKM Bangi, Selangor Darul Ehsan

Malaysia

*Corresponding author; email: joe@ukm.edu.my

Received: 5 February 2018

Accepted: 31 May 2018 